\title{
IONIC EXCHANGE STUDIES FOR CORRECTING WATER QUALITY INDICATORS
}

\author{
SILVIA BURCĂ ${ }^{\mathrm{a}}$, CERASELLA INDOLEAN ${ }^{\mathrm{a} *}$
}

\begin{abstract}
For this study, a natural ionic exchanger (zeolitic volcanic tuff) and a synthetic anionic exchanger were considered, to remove iron and manganese ions, reduce COD, chlorides and conductivity values from water. It was worked with a zeolitic volcanic tuff cropped out from Macicas area, Romania, and a synthetic anionic exchanger Amberlite A-21. A groundwater and surface sources of drinking water from lalomiţa-Muntenia (Romania) catchment were analysed, with iron and manganese contents (0.2527$0.3059 \mathrm{mg} \mathrm{Fe}$ tot/L, $0.0234 \mathrm{mg} \mathrm{Mn} / \mathrm{L})$, COD (14.530-17.064 mg KMnO$/ \mathrm{L})$, chlorides contents $(170.95 \mathrm{mg} / \mathrm{L}), \mathrm{pH}=7.70$, and with electrical conductivity of $1433-1451 \mu \mathrm{S} / \mathrm{cm}$. The ionic exchange process has been achieved in batch and continuous-flow conditions. The process was realized in static regime, with good results, the highest efficiencies for iron and manganese ions removal being $99 \%$ and $79-95 \%$, respectively.
\end{abstract}

Keywords: municipal water source, food water, zeolitic volcanic tuff, ionic exchange

\section{INTRODUCTION}

The availability of adequate freshwater resources, is vital to food safety and production (primary such as irrigation, livestock watering, aquaculture and processing: ingredient, transport medium and hygiene aid) [1].

If the water is drinkable, then, it could be accepted for all food uses [2]. However, not all uses require that water to be of this standards and, where it is possible, it can use other sources of water or reuse water. Consequently, the water quality requirements will need to be appropriately tailored [3-6].

\footnotetext{
a Babeş-Bolyai University, Faculty of Chemistry and Chemical Engineering, 11 Arany Janos str., RO-400028, Cluj-Napoca, Romania *Corresponding author: cella@chem.ubbcluj.ro
} 
Water, like food, is a potential vehicle for the transmission of diseases, causing agents or chemicals toxic and/or dangerous for health. Water is capable of introducing contamination into food, if appropriate care is not taken [7]. Raw water can be contaminated with pathogens, usually as a consequence of human or animal faecal material or run-off contaminated with faecal material. It can also be contaminated with a wide range of chemicals, both natural and anthropogenic, which are of concern under some circumstances, depending on the concentrations present. Contamination can arise in raw water or as a consequence of improper storage or pick-up of contaminants from distribution systems. It can also occurs as a consequence of leakage from a dirty water system into a clean water system. For example, drinking water was identified as the source of a significant and fatal outbreak of Escherichia coli O157:H7 in Canada [8].

In areas where groundwater flows through an organic rich soil, iron and manganese will also dissolve there. Natural sources of iron and manganese may include weathering of iron and manganese bearing minerals (olivine, magnetit, chromit, ilmenite, pyrrhotit, pyrite, hematit, hydrate, geothit, lepidokrokit, iron carbonate, vivianit, strengit) [9]. The soils can have iron content between $0.5 \%$ and $5 \%$, depends on the rocks from where soil was derived, mechanism of transport and geochemical history. Iron and manganese release in water can have anthropogenic sources: industrial effluents, landfill leakages and acid mine drainage, but also well casing, pump parts, piping and storage tank [10].

The too high concentrations of $\mathrm{Mn}^{2+}$ will have as a consequence a metallic taste of water, staining of different products like clothes, paper and plastics [11].

Iron and manganese can cause different types of nuisance problems. The colour and flavour of food and water can be affected by iron and manganese, because they can react with tannins in coffee, tea and alcoholic beverages, which conduct of black sludge obtaining. Iron can cause reddish-brown staining of laundry, utensils, dishes and glassware [12]. Iron and manganese can also cause build up in pipelines, water heaters and pressure tanks. This build up is linked with a decrease in pressure and amount of available water and also increase in cost of water-using appliances [13]. The deposition of iron and manganese in the distribution systems can cause reduction of diameter of pipes and eventually clogging of those will take place [14].

The removal of dissolved iron and manganese from groundwater is generally accomplished by the oxidation and precipitation. The removal process is affected by the different chemical and physical characteristics of water: $\mathrm{pH}$, temperature, total organic carbon (TOC) and concentration of dissolved oxygen [15]. It can use the ion exchange method, if the aim is to 
remove small quantities of iron and manganese, because it will be the risk of rapid clogging. The process of iron and manganese removing by ion exchange is accomplished by using strong acid cations [16].

In the brewery industry, for example, water is an essential component for the final product quality, together with yeast, barley and hops, and breweries pay great attention on sourcing of this raw material. The production and processing of high quality water is a very important factor, due to its influence on both the production process (yeast requires potassium, sodium and calcium for optimum fermentation) and on the taste of the final product $[17,18]$. Aside from these requirements, there is legislation governing water quality parameters in such industries, obliging brewers to use high drinking quality water for most production processes [19, 20].

In this study, zeolitic volcanic tuff and cationic exchanger were used to retain iron and manganese ions, and reduce the concentration of dissolved salts, in order to obtain adequate quality water for use in the brewery industry.

\section{RESULTS AND DISCUSSION}

Samples of drinking water collected from lalomiţa-Muntenia (Romania) catchment (groundwater and surface water sources) are characterized by a high content of dissolved salts, iron and manganese concentration, close to the maximum allowable value (MVA). The initial $\mathrm{pH}$ was around neutral. The presence of ammonium and nitrite ions in samples was not detected. The measured values of physico-chemical indicators are shown in Table 1.

Table 1. Physico-chemical indicators values for lalomiţa-Muntenia (Romania) catchment

\begin{tabular}{|c|c|c|c|c|c|c|}
\hline $\begin{array}{l}\text { Water } \\
\text { Sample }\end{array}$ & $\begin{array}{l}\text { Fetot } \\
\mathrm{mg} / \mathrm{L}\end{array}$ & $\begin{array}{l}\mathrm{Mn}^{2+} \\
\mathrm{mg} / \mathrm{L}\end{array}$ & $\begin{array}{c}\mathrm{COD} \\
\mathrm{mg} \mathrm{KMnO}_{4} / \mathrm{L}\end{array}$ & $\begin{array}{c}\mathrm{Cl}^{-} \\
\mathrm{mg} / \mathrm{L}\end{array}$ & $\begin{array}{c}\text { Conductivity } \\
\mu S / \mathrm{cm}\end{array}$ & $\mathrm{pH}$ \\
\hline Groundwater (GW) & 0.305 & 0.023 & 14.536 & 177.90 & 1433 & 7.6 \\
\hline Surface water (SW) & 0.252 & 0.023 & 17.064 & 170.95 & 1451 & 7.7 \\
\hline
\end{tabular}

Batch mode analysis

Experimental determinations, in static regime, showed that the equilibrium of the iron and manganese ions removal by ion exchange on ZVT$\mathrm{H}$ was reached after 24 hours. Concentrations of the iron and manganese ions are very small in the samples collected, below the MVA, imposed by the Romanian legislation (50 $\mu \mathrm{g} \mathrm{Mn}^{2+} / \mathrm{L}$ and $200 \mu \mathrm{g} \mathrm{Fe}$ total $\mathrm{L}$ [21], Figure 1 and Figure 2). 
High values of cationic exchange process efficiencies were found (95-97\%, for the $\mathrm{Fe}_{\text {tot }}$ removal ions, respectively $79.5-95 \%$, in the case of manganese ions).

Chloride ion concentrations, determined in water samples, collected at equilibrium, were found to be around $35.45-37.48 \mathrm{mg} \mathrm{Cl} / \mathrm{L}$ and the efficiencies of anionic exchange process were between 77.77 and $79.25 \%$.

Regarding at COD analysis of drinking water samples, this parameter has decreased from $14.53 \mathrm{mg} \mathrm{KMnO}_{4} / \mathrm{L}$, respectively $17.06 \mathrm{mg} \mathrm{KMnO} 4 / \mathrm{L}$ to $4.26 \mathrm{mg} \mathrm{KMnO}_{4} / \mathrm{L}$ respectively $9.10 \mathrm{mg} \mathrm{KMnO}_{4} / \mathrm{L}$ (values recorded at the end of the cationic/anionic exchange process), values found to be below the maximum allowed by Romanian law.

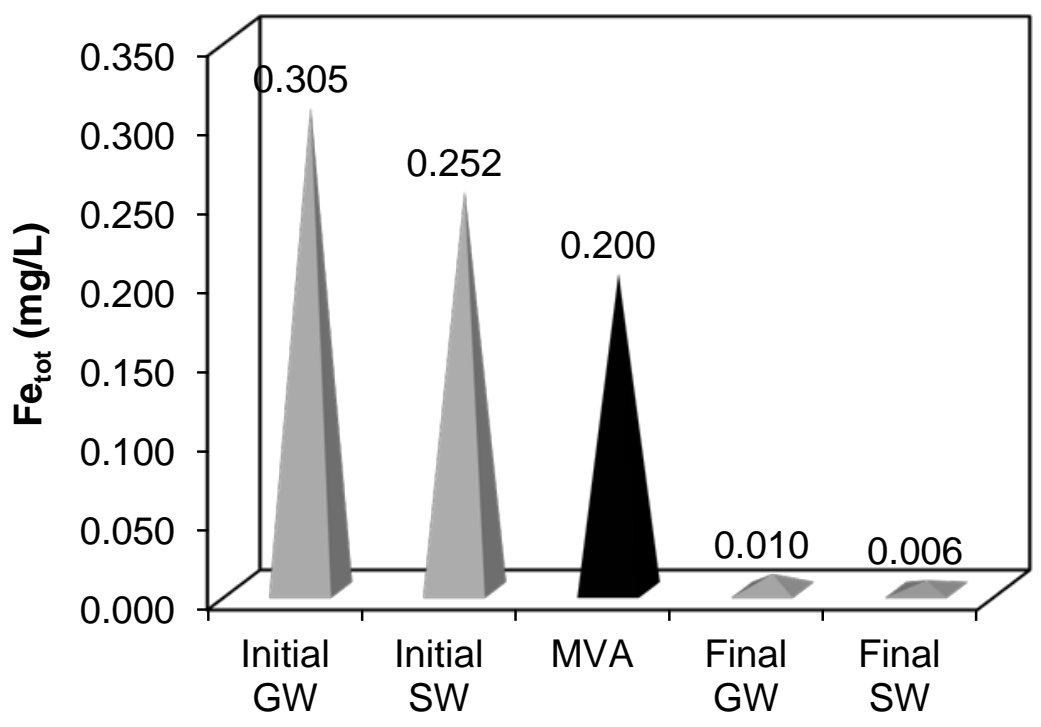

Figure 1. Initial, MVA and equilibrium iron ions concentration values, GW and SW samples, cationic exchange, static regime, $2 \mathrm{~g}$ ZVT-H, $100 \mathrm{~mL}$ sample, room temperature.

Electrical conductivity, measured at the end of the cationic/anionic exchange process, in static regime, presents a sharply decreased from 1433 $\mu \mathrm{S} / \mathrm{cm}(\mathrm{SW})$ and $1451 \mu \mathrm{S} / \mathrm{cm}(\mathrm{GW})$, to $428 \mu \mathrm{S} / \mathrm{cm}$ (SW) and $514 \mu \mathrm{S} / \mathrm{cm}$ (GW), respectively. MAV value, according to Romanian legislation, is 2500 $\mu \mathrm{S} / \mathrm{cm}[21]$. 


\section{Fixed bed column analysis}

The breakthrough curves for $\mathrm{Fe}_{\text {tot }}$ and $\mathrm{Mn}^{2+}$ sorption on $\mathrm{ZVT}-\mathrm{H}$, at an inlet concentration of $0.252 \mathrm{mg} \mathrm{Fe}$ tot $/ \mathrm{L}$ and $0.023 \mathrm{mg} \mathrm{Mn}^{2+} / \mathrm{L}$ are shown in Figure 3. As it was expected, $\mathrm{Fe}_{\text {total }}$ and $\mathrm{Mn}^{2+}$ sorption was very high, in 370400 minutes, and then the concentration at the column outlet increased slowly, because the zeolitic volcanic tuff was getting saturated.

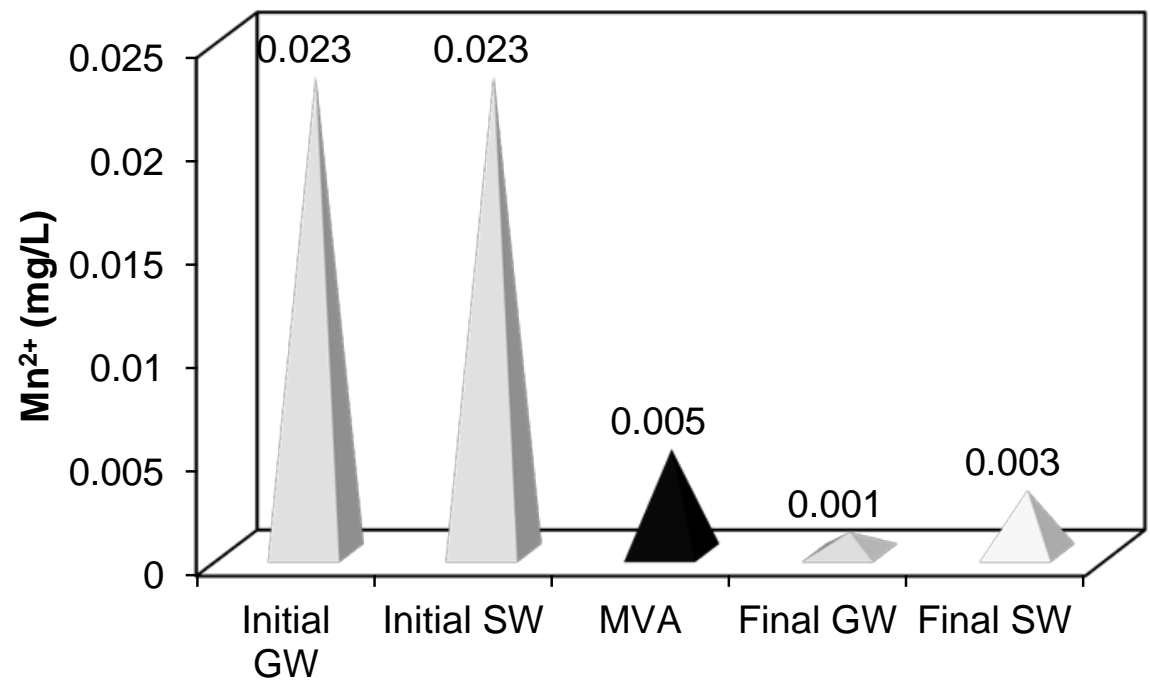

Fig. 2. Initial, MVA and equilibrium manganese ions concentrations, cationic exchange, static regime, $2 \mathrm{~g}$ ZVT-H, $100 \mathrm{~mL}$ sample, room temperature.

The values of the breakthrough time $\left(\mathrm{t}_{\mathrm{b}}\right)$ and exhaustion time $\left(\mathrm{t}_{\mathrm{s}}\right)$, of the breakthrough curves, obtained for iron and manganese ions were $10.6 \mathrm{~h}$ and $38.89 \mathrm{~h}$ respectively, for manganese ions sorption, $32.82 \mathrm{~h}$ and $36.86 \mathrm{~h}$, respectively for iron ions sorption. It can be observed that the values of breakthrough time for manganese ions was almost three times smaller than breakthrough time for sorption of iron ions (10.6 $\mathrm{h}$ for manganese ions, compared to $32.82 \mathrm{~h}$, for iron ions).

MVA for manganese ions has a lower value than the MVA for iron ions (0.005 $\mathrm{mg} \mathrm{Mn}^{2+} / \mathrm{L}$, compared to $0.200 \mathrm{mg} \mathrm{Fe}_{\text {tot }} / \mathrm{L}$ ) [22].

It was found that the maximum sorption capacity values of iron ions is higher than the maximum sorption capacity values for manganese ions $(0.543$ $\mathrm{mg} \mathrm{Fe}$ tot $/ \mathrm{ZZVT}-\mathrm{H}$ compared to $0.044 \mathrm{mg} \mathrm{Mn}^{2+} / \mathrm{g} \mathrm{ZVT-H}$, respectively), because the inlet concentration of iron ions is higher than inlet concentration of manganese ions (Figure 4 and Figure 5). 
SILVIA BURCĂ, CERASELLA INDOLEAN

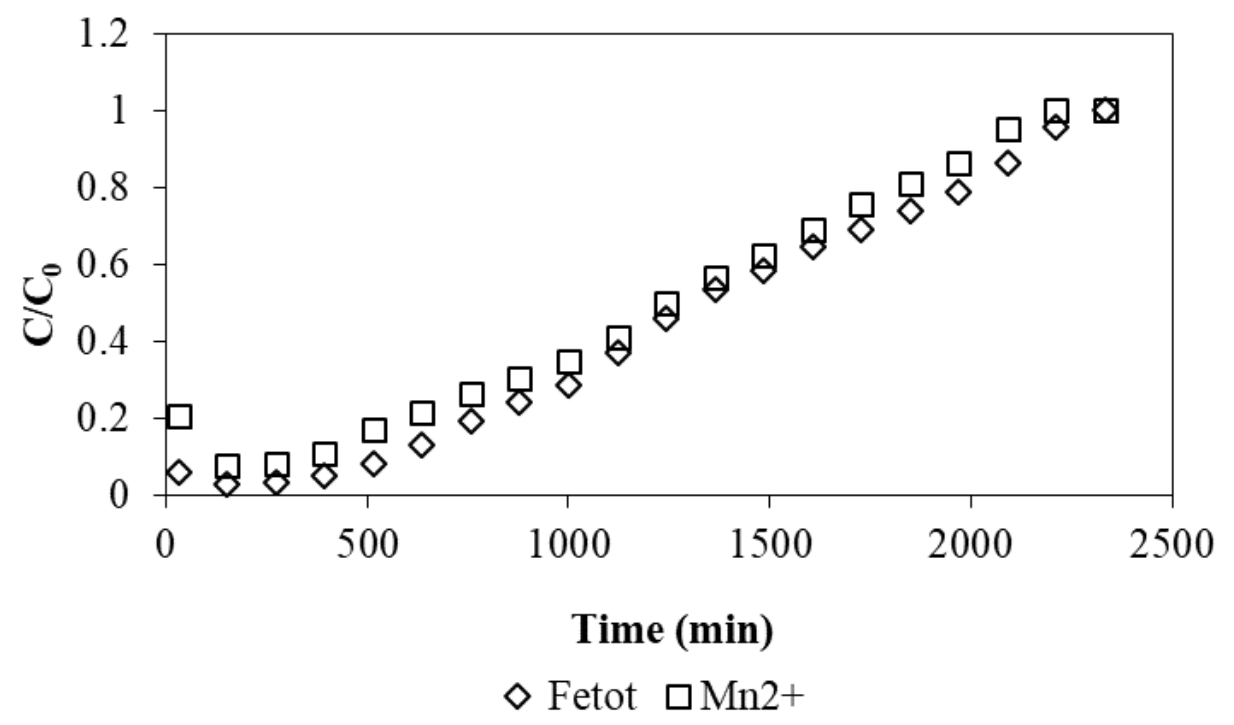

Figure 3. Breakthrough curves for iron and manganese ionic exchange process, on ZVT-H, dynamic regime.

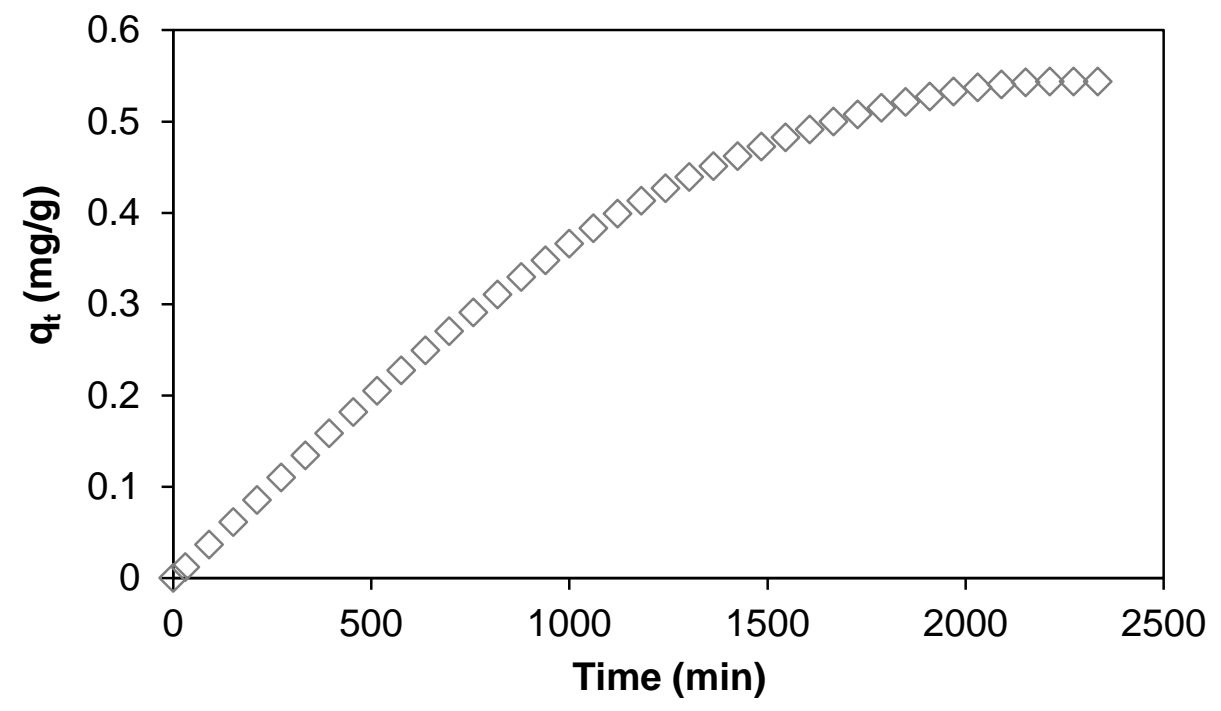

Figure 4. Removal capacity for Fetot sorption, $2 \mathrm{~g} Z V T-H, Q=0.055 \mathrm{~mL} / \mathrm{s}$, $\mathrm{C}_{0}=0.252 \mathrm{mg} / \mathrm{L}$. 
IONIC EXCHANGE STUDIES FOR CORRECTING WATER QUALITY INDICATORS

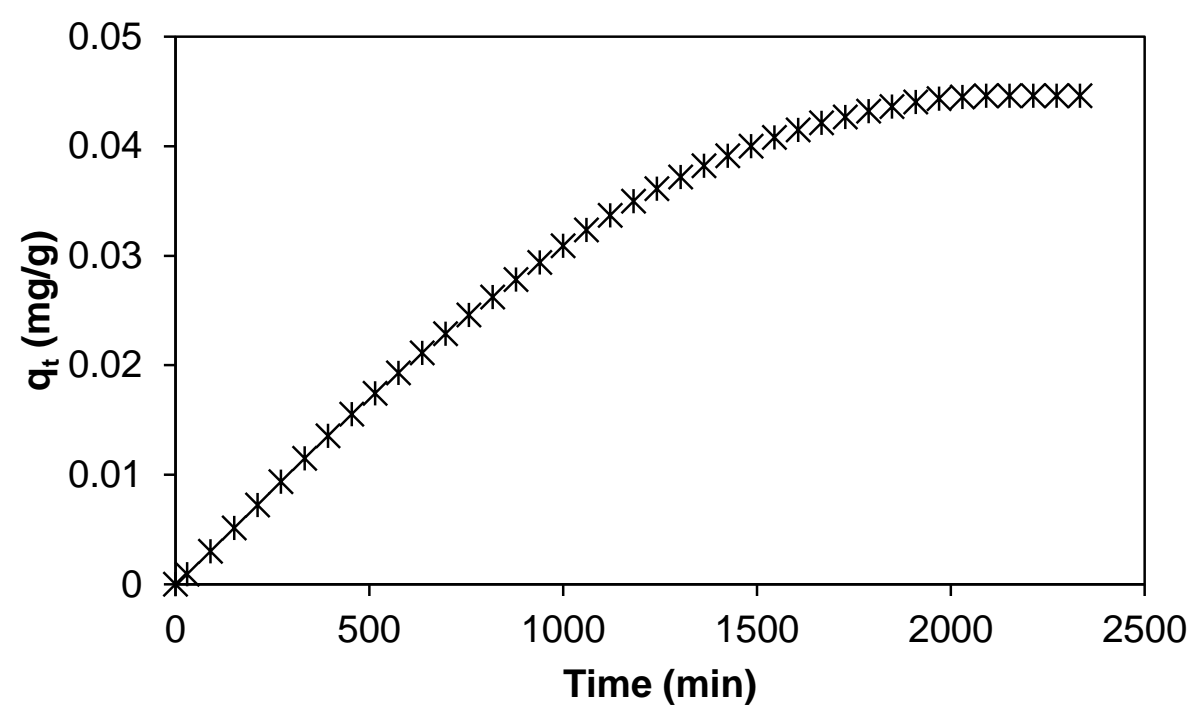

Figure 5. Removal capacity for $\mathrm{Mn}^{2+}$ sorption, $2 \mathrm{~g}$ ZVT-H, $\mathrm{Q}=0.055 \mathrm{~mL} / \mathrm{s}, \mathrm{C}_{0}=0.023 \mathrm{mg} / \mathrm{L}$

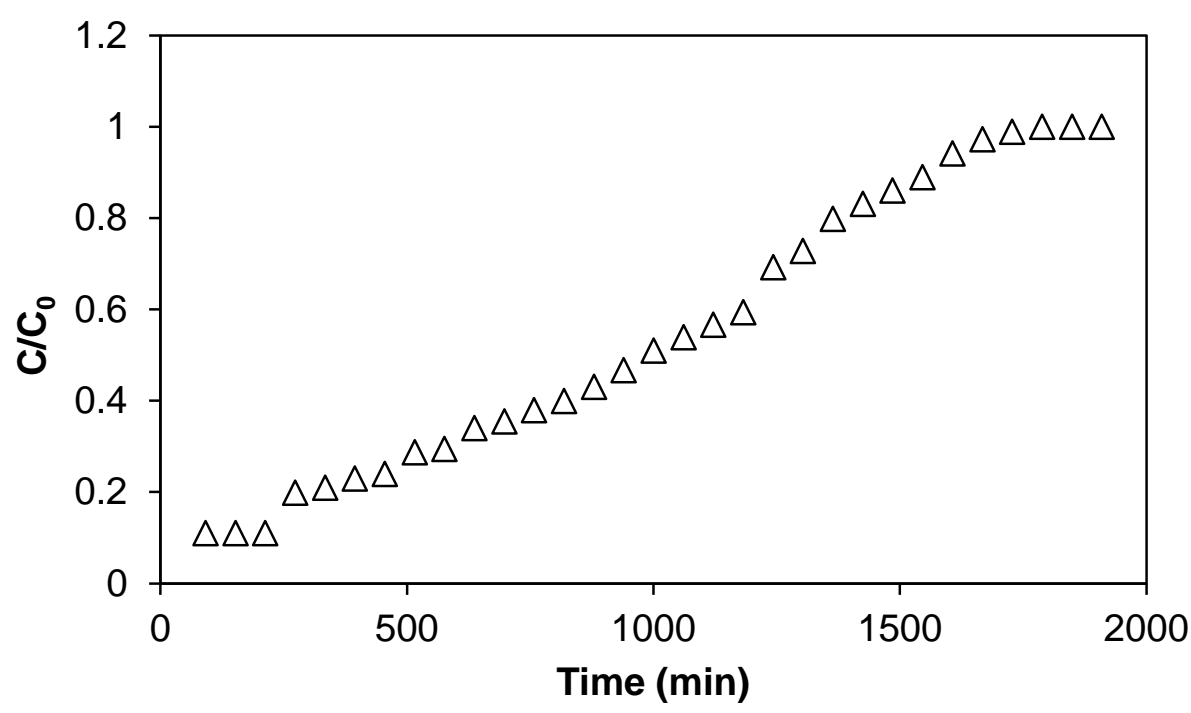

Figure 6. Breakthrough curve for $\mathrm{Cl}^{-}$sorption, $2 \mathrm{~g} \mathrm{A-21}$ anionic exchanger, $\mathrm{C}_{0}=170.95 \mathrm{mg} \mathrm{Cl} / \mathrm{L}, \mathrm{Q}=0.055 \mathrm{~mL} / \mathrm{s}$. 
The breakthrough curve for $\mathrm{Cl}^{-}$sorption, on synthetic resin Amberlite A-21, with an inlet concentration of $170.96 \mathrm{mg} \mathrm{Cl} / / \mathrm{L}$ is shown in Figure 6 . The exit time value $\left(\mathrm{t}_{\mathrm{s}}\right)$ of the breakthrough curves obtained for chlorides ions was $41.91 \mathrm{~h}, \mathrm{MVA}$ for chlorides ions in the drinking water being $250 \mathrm{mg} \mathrm{Cl} / \mathrm{L}$ [22]. The maximum sorption capacity values of chlorides ions was $98.85 \mathrm{mg} \mathrm{Cl} / \mathrm{g}$, Figure 7.

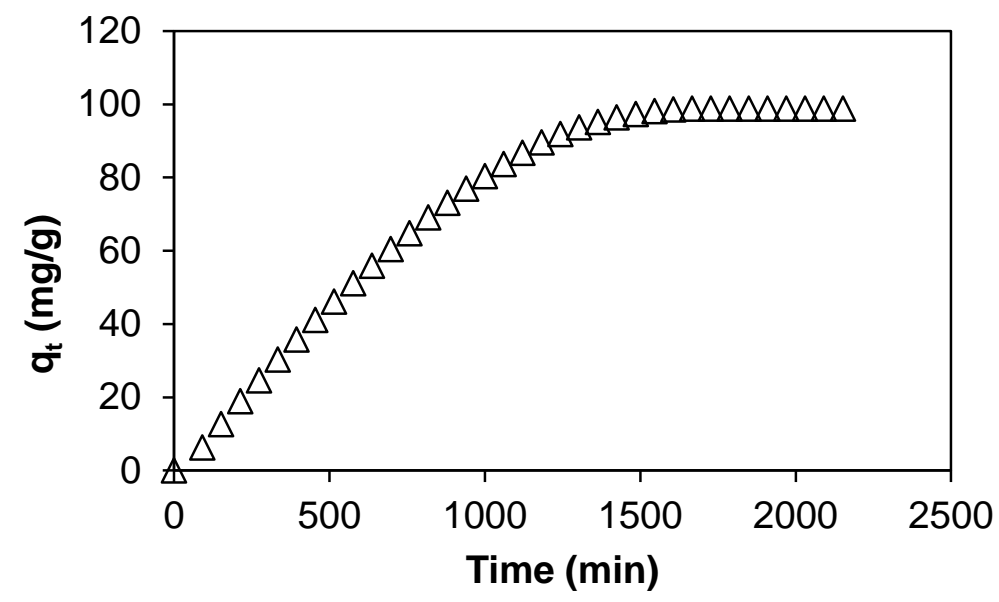

Figure 7. Removal capacity for chlorides sorption, 2 g A-21, $\mathrm{Q}=0.055 \mathrm{~mL} / \mathrm{s}, \mathrm{C}_{0}=170.95 \mathrm{mg} \mathrm{Cl} / \mathrm{L}$.

\section{Breakthrough curves modeling}

To describe the fixed bed column behaviour and to scale it up for industrial applications, three models - Thomas, Wolborska, and YoonNelson - were used, in order to fit better the experimental data with the appropriate model.

\section{Thomas model}

This model is suitable for adsorption process where the external and internal diffusion limitations are absent, this is frequently applied to estimate the adsorptive capacity of adsorbent and predict breakthrough curves, assumes plug flow behavior in the bed, uses Langmuir isotherm for equilibrium and second order reversible reaction kinetics $[23,24]$.

Adsorption kinetics is described as the following equation:

$$
\frac{\partial \mathrm{q}}{\partial \mathrm{t}}=k_{1}\left(q_{0}-q\right) C-k_{2} q\left(C_{0}-C\right)
$$


where: $k_{1}$ and $k_{2}$ are velocity constants $\left(\mathrm{s}^{-1}\right)$

$\mathrm{q}_{0}$ is the initial exchange capacity $(\mathrm{mg} / \mathrm{g})$,

$\mathrm{C}_{0}$ is the inlet concentration $(\mathrm{mg} / \mathrm{L})$. becomes:

By applying boundary conditions and linearization, the equation

$$
\ln \left(\frac{C_{0}}{C}-1\right)=\frac{k_{T} q_{0} m_{c}}{Q}-k_{T} C_{0} t
$$

where: $\mathrm{k}_{\mathrm{T}}$ is the Thomas rate constant $\left(\mathrm{dm}^{3} /(\mathrm{s} \cdot \mathrm{g})\right)$,

$\mathrm{q}_{0}$ is the adsorption capacity $(\mathrm{mg} / \mathrm{g})$,

$m_{c}$ is the ionic exchanger mass in the column (g),

$V_{\text {eff }}$ is the throughput volume $(L)$,

$\mathrm{Q}$ is the volumetric flow rate $\left(\mathrm{dm}^{3} / \mathrm{s}\right)$,

$\mathrm{t}=\mathrm{V}_{\text {eff }} / \mathrm{Q}$.

For the cationic/anionic exchange experimental data, a plot of $\ln \left(\mathrm{C}_{0} / \mathrm{C}-1\right)$ vs. $t$ should give a linear relationship, if the above model is correct.

In Figure 8 is presented a linear regression of the cationic exchange experimental data, showing a $\mathrm{R}^{2}$ value of 0.9776 . However, it is visible from the shape of the curve that the relationship is linear. For the anionic exchange process, $R^{2}$ value was 0.9128 .

The determined coefficients and relative constants, obtained for kinetics considered models are shown in Table 2.

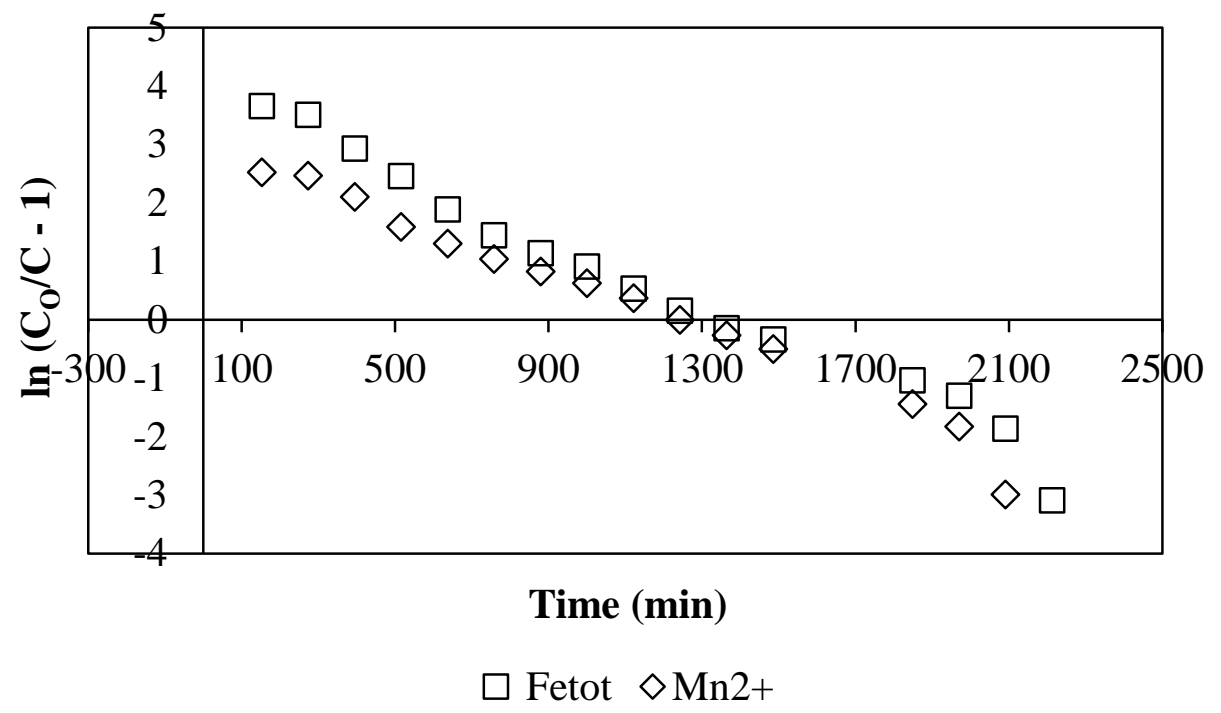

Figure 8. Thomas model linear regression, cationic exchange. 


\section{Wolborska Model}

Wolborska found that the breakthrough had two regions in which the migration rate of the concentration front is described in different ways [25]: low concentration region, in the range from $10^{-5}$ to $5 \times 10^{-2}$ of the normalized outlet concentration $\left(\mathrm{C}_{\text {outlet }} / \mathrm{C}_{\text {inlet }}\right)$ and high concentration region, containing the other range of the curve.

The model developed by Wolborska is exclusively for the low concentration region of the breakthrough curve and based on the following observations from Dubinin et al [26]: the initial concentration distribution is translocated along the column at a constant, velocity, the width of the breakthrough curve in the range of low concentration is constant, the low concentration area is characterized by constant kinetic coefficients, the process rate is controlled by the external mass transfer resistance [27].

Below is presented the continuity equation on the column:

$$
\frac{\partial C}{\partial t}+u \frac{\partial C}{\partial h}+\frac{\partial q}{\partial t}=D \frac{\delta^{2} C}{\delta h^{2}}
$$

where: $\mathrm{C}$ is the adsorbate concentration $(\mathrm{mg} / \mathrm{L})$,

$\mathrm{t}$ is time (min),

$u$ is the flow rate $(L / m i n)$,

$\mathrm{q}$ is the adsorbate concentration in the solid phase ( $\mathrm{mg} / \mathrm{g}$ adsorbent),

$D$ is axial diffusion coefficient,

$h$ is the distance from the column inlet (dm).

By applying boundary conditions and linearization, equation the equation becomes:

$$
\ln \frac{C}{C_{0}}=\frac{\beta_{a} C_{0}}{q_{0}} t-\frac{\beta_{a}}{u} h
$$

where $\beta_{a}=\beta_{0}$ for process without axial diffusion and $\beta_{a}=$ $\frac{u^{2}}{2 D}\left(\sqrt{1+\frac{4 \beta_{0} D}{u^{2}}}-1\right)$ for column dynamics with axial dispersion.

By plotting $\ln \left(\mathrm{C} / \mathrm{C}_{0}\right)$ versus $\mathrm{t}$ of the experimental data, the resulting curve would be linear, if the Wolborska model is the appropriate for the experimental data. From Figure 9, it can be seen that the relationship is linear for anionic exchange process and, in this case, the $R^{2}$ value is 0.9854 . For the cationic exchange process (iron and manganese sorption on ZVT-H) the Wolbraska model does not fit properly with the experimental data. 


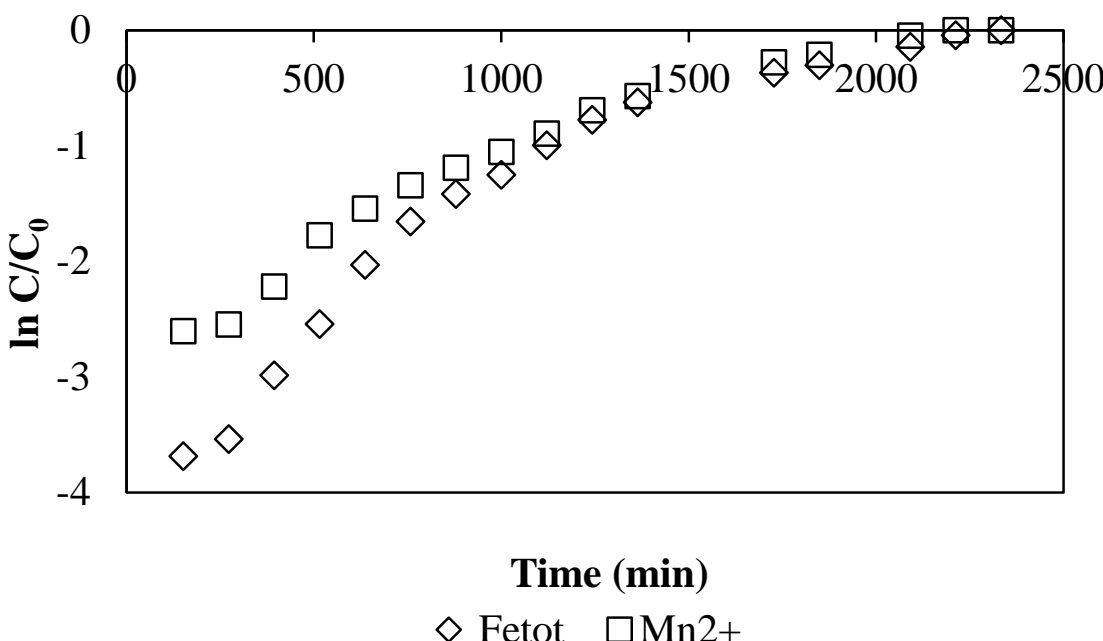

Figure 9. Wolborska model liniar regresion, iron and manganese ions, ZVT-H, cationic exchange.

Yoon and Nelson Model

Kinetic adsorption model developed by Yoon and Nelson [28] is based on the assumption that the rate of decrease in the probability of adsorption for each adsorbate molecule is proportional to the probability of adsorbate adsorption and the probability of adsorbate breakthrough, on the adsorbent.

The Yoon and Nelson model has the following differential form:

$$
-\frac{d Q}{d t}=\frac{k C U}{m_{a}} Q P
$$

where $\mathrm{Q}$ is the probability for adsorption, (\%),

$\mathrm{P}$ is the probability for breakthrough, (\%),

$\mathrm{t}$ is time, (s).

Experimental evidence also shows that the rate of decrease in the probability of adsorption is directly proportional to the contaminant concentration, $C(\mathrm{~g} / \mathrm{L})$, and the volumetric flow rate $U(\mathrm{~L} / \mathrm{s})$, and inversely proportional to the weight of the adsorbent $m_{a}(g)$ [28].

$$
\frac{k C U}{m_{a}}=k_{Y N}
$$

Solving the above differential equation, using the boundary condition at $50 \%$ breakthrough, $t=t_{0.5}, Q=1 / 2$ and $P=1 / 2$, following solution is given: 


$$
\ln \left(\frac{C}{C_{0}-C}\right)=k_{Y N} t-t_{0.5} k_{Y N}
$$

where $\mathrm{C}_{0}$ is the inlet concentration, $\mathrm{mg} / \mathrm{L}$.

In case of Yoon-Nelson, Figure 10 and Table 2, the results obtained suggested that the considered models do not fit properly with the experimental data for iron manganese sorption on ZVT-H and chlorides ions on anionic resin A-21 (small correlation coefficients were obtained).

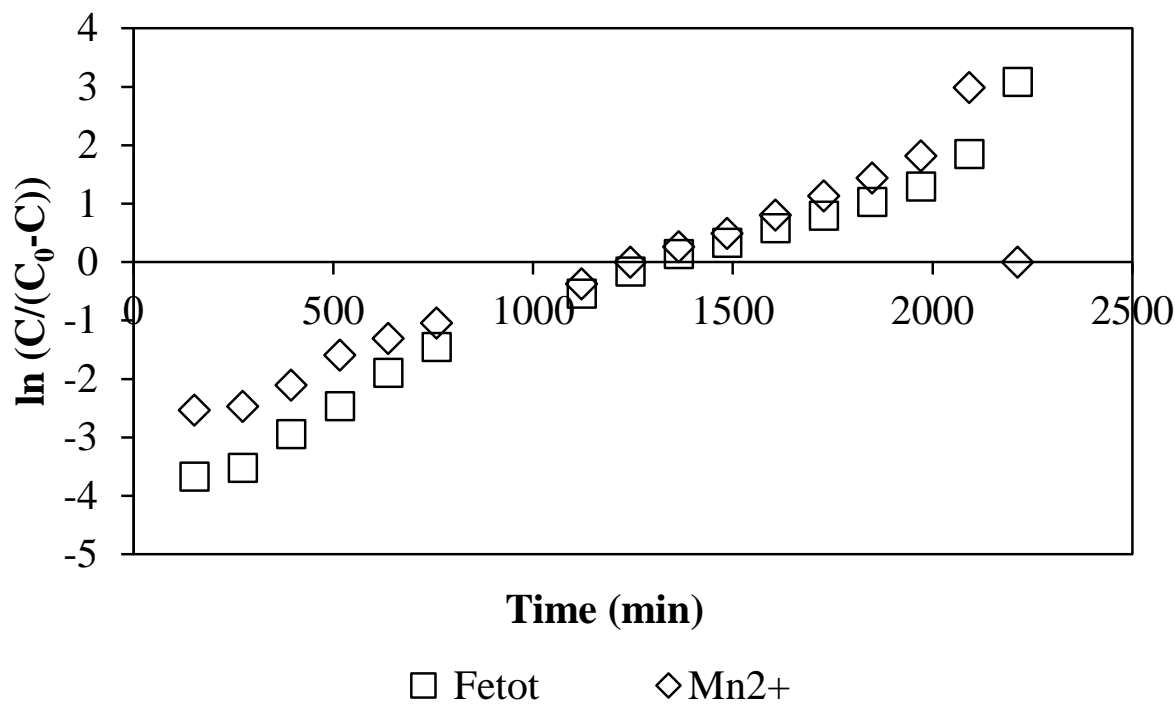

Figure 10. Yoon and Nelson model linear regression, iron and manganese, ZVT-H, cationic exchange.

Table 2. Thomas, Wolborska, Yoon and Nelson parameters for $\mathrm{Fe}_{\text {tot, }} \mathrm{Mn}^{2+}$ and $\mathrm{Cl}^{-}$ sorption at ZVT-H and Amberlite A-21 anionic resin.

\begin{tabular}{|c|c|c|c|c|c|c|c|c|c|}
\hline \multirow[b]{2}{*}{$\begin{array}{l}\frac{n}{0} \\
\frac{0}{\frac{0}{0}} \\
\frac{0}{0} \\
\frac{0}{\Sigma}\end{array}$} & \multicolumn{3}{|c|}{ Thomas } & \multicolumn{3}{|c|}{ Wolborska } & \multicolumn{3}{|c|}{ Yoon-Nelson } \\
\hline & 음 & 至 & $\tilde{\simeq}$ & 㒸 & ㅇํㅇ & $\tilde{\nwarrow}$ & 审 & $\stackrel{\stackrel{\leftrightarrow}{s}}{s} \cdot \frac{\tilde{E}}{\varepsilon}$ & $\approx$ \\
\hline $\mathrm{Fe}_{\text {tot }}$ & 0.69 & $1.151 \cdot 10^{-2}$ & 0.977 & 6.737 & 1.41 & 0.930 & 2.2 & 29.98 & 0.848 \\
\hline $\mathrm{Mn}^{2+}$ & 0.074 & $1.087 \cdot 10^{-1}$ & 0.977 & 9.025 & 0.129 & 0.886 & 2.9 & 22.60 & 0.977 \\
\hline $\mathrm{Cl}^{-}$ & 116.81 & $1.88 \cdot 10^{-5}$ & 0.912 & 5.567 & 144.25 & 0.985 & 3.5 & 14.15 & 0.912 \\
\hline
\end{tabular}




\section{CONCLUSIONS}

Two materials, a natural ionic exchanger (zeolitic volcanic tuff) and a synthetic anionic exchanger were utilized to remove iron and manganese ions, chlorides and to reduce conductivity and COD values from ground water (GW) and surface water (SW) samples, from lalomiţa-Muntenia (Romania) catchment.

When the experimental determinations were conducted in static regime, it was found that the equilibrium of the iron and manganese ions removal was reached after 24 hours, utilizing an ion exchange process, on ZVT-H.

In dynamic regime, the values of breakthrough time for manganese ions was almost three times smaller than breakthrough time for sorption of iron ions (10.6 $\mathrm{h}$ for manganese ions, compared to $32.82 \mathrm{~h}$, for iron ions).

The maximum sorption capacity values for $\mathrm{Fe}_{\text {tot }}$ is higher than the maximum sorption capacity values for $\mathrm{Mn}^{2+}(0.543 \mathrm{mg} \mathrm{Fe}$ tot $\mathrm{g}$ ZVT-H compared to $0.044 \mathrm{mg} \mathrm{Mn}^{2+} / \mathrm{g}$ ZVT-H).

To describe the fixed bed column behaviour and to scale it up for industrial applications, three models - Thomas, Wolborska and Yoon-Nelson - were used, in order to fit the experimental data with the suitable model.

Good agreement between the predicted theoretical breakthrough curves and the experimental results were observed for Thomas model, in the case of $\mathrm{Fe}_{\text {tot }}$ and $\mathrm{Mn}^{2+}$ ions (correlation coefficients of 0.977), and for Wolborska model, in the case of $\mathrm{Cl}^{-}$ions (correlation coefficients of 0.985 ).

\section{EXPERIMENTAL SECTION}

Ionic exchanger

In this study was used zeolitic volcanic tuff (ZVT) from Măcicaş (M), Romania. The sedimentary zeolitic rocks belong to the Dej Tuff Complex of a Lower Badenian age [21]. According to our previous studies of the ZVT from this outcrop, the main zeolite present in these rocks is clinoptilolite, representing $60-70 \%$ of the total mineral phases [22- 24]. ZVT samples were first subjected to a physical treatment (grinding, size separation, washing) followed by an acide treatment [29-30].

Beside the ZVT in $\mathrm{H}$ form (ZVT-H) sample and anionic resin Amberlite 21 (A-21)(Sigma-Aldrich) were also used. The synthetic exchanger considered is dimethylamino-resin (weakly basic), with maximum temperature operating of $100^{\circ} \mathrm{C}$, moisture content $57 \%$, surface area $25 \mathrm{~m}^{2} / \mathrm{g}$, porosity $48 \%$ and total exchange capacity $1.3 \mathrm{meq} / \mathrm{ml}, 4.8 \mathrm{meq} / \mathrm{g}$ respectively. 


\section{Water sampling and analysis}

For the ionic exchange study it were used drinking water samples from lalomiţa-Muntenia (Romania) catchment. Water samples were characterized using the physico-chemical methods according to Romanian legislation (Laws 458/2002, 311/2004). The following water quality parameters were determined: $\mathrm{pH}$, chemical oxygen demand (COD) in $\mathrm{mg} \mathrm{KMnO}_{4} \mathrm{mg} / \mathrm{L}$, electrical conductivity $(\mu \mathrm{S} / \mathrm{cm}), \mathrm{Mn}^{2+}, \mathrm{Fe}_{\text {total }}, \mathrm{Cl}^{-}, \mathrm{NO}_{2}{ }^{-}, \mathrm{NH}_{4}{ }^{+}(\mathrm{mg} / \mathrm{L}) . \mathrm{pH}$ and electrical conductivity were determined using a Consort C863 pH meter (SR ISO 10523/96, SR ISO 7887/97). Chemical oxygen demand and chlorides were determined by volumetric method (Romanian STAS 7313-82, STAS 3326-76, STAS 3002-85). Concentration of $\mathrm{Mn}^{2+}, \mathrm{Fe}_{\text {total }}, \mathrm{NO}_{2}{ }^{-}$and $\mathrm{NH}_{4}{ }^{+}$were determined using molecular absorption (SR 8662-1, 2/96, SR 13315/96, STAS 3048/2-96, STAS 6328/85) with a UV VIS Spectrometer Jenway 6305. Each sample was measured three times, the averaged values were presented.

Ionic exchange experiments

The cationic exchange process was realised in batch reactor, in static regime using $2 \mathrm{~g}$ of the $0.2-0.4 \mathrm{~mm}$ particle size of ZVT-H and $100 \mathrm{ml}$ water (exchanger: water $=2: 100$ ). Solution samples were collected every $24 \mathrm{~h}$ for iron, manganese and COD concentrations measurement, until the equilibrium was reached. Then anionic exchange process was conducted under the same conditions (static regime, $2 \mathrm{~g}$ of the anionic resin A-21 and $50 \mathrm{ml}$ water), samples were collected for chloride concentration measurement, until the equilibrium was reached.

It also worked in dynamic regime, on a two fixed bed columns $\left(\mathrm{d}_{\mathrm{i}}=14.5\right.$ $\mathrm{mm}$ ), containing $2 \mathrm{~g}$ of the $0.2-0.4, \mathrm{~mm}$ grain size ZVT-H, respectively $2 \mathrm{~g}$ anionic resin A-21. It was worked with a flow rate of $0.055 \mathrm{~mL} / \mathrm{s}$. The effluent was collected at the outflow of the column every $100 \mathrm{~mL}$, until the zeolitic volcanic tuff and anionic resin have been exhausted, in order to determine the exact concentration of iron and manganese ions, respectively chloride concentration and also, their evolution during the ionic exchange process.

Experiments were carried out without any modification of temperature (room temperature).

Exchange capacities, CEC, q in mg/g ZVT-H, mg/g A-21, and removal efficiencies, $E(\%)$, were calculated to establish the efficiency of the considered process [31].

$$
q=\frac{c_{0}-c_{e}}{m} \cdot \frac{V}{1000} \quad\left(\text { batch mode) (8) } \quad q_{t}=\frac{c_{0}-c_{e}}{m} \cdot \frac{V}{1000}+q_{t-1}\right.
$$

(fixed bed) 


$$
E(\%)=\frac{C_{0}-C_{e}}{C_{0}} \cdot 100
$$

where:

$\mathrm{C}_{0}, \mathrm{C}_{\mathrm{e}}$ are the initial and equilibrium zinc ion concentrations ( $\left.\mathrm{mg} / \mathrm{L}\right)$;

$\mathrm{q}$ is the ionic exchange capacity $(\mathrm{mg} / \mathrm{g})$,

$V$ is the volume of water $(\mathrm{mL})$,

$m$ is the mass of ionic exchanger $(g)$.

The kinetics of iron and manganese sorption on ZVT-H respectively chloride sorption on Amberlite A-21, was studied taken into consideration the three models: Thomas, Wolbraska and Yoon-Nelson.

\section{REFERENCES}

1. R.S. Ayers, DW. Westcot DW, "Water quality for agriculture. FAO irrigation and drainage", 29, Rome. ISBN 92-5-102263-1, 1976.

2. S. Barlow, G. Kozianowski, G. Wurtzen, J. Schlatter, Chemical Toxicology, 2001;39, 893.

3. T. Asano, F.L. Burton, H. Leverenz, R. Tsuchihashi, G. Tchobanoglous, "Water reuse: issues, technologies and applications", New York, McGraw-Hill, 2007.

4. J. Bartram, T. A. Stenstrom, L. Fewtrell, "Harmonised assessment of risk for water-related microbiological hazards: an overview". In: L. Fewtrell, J. Bartram, (eds) Water-quality: guidelines, standards and health - risk assessment and management for water-related infectious disease. IWA, London, for the WHO; 2001.

5. G. Bitton, R. Harvey, "Transport of pathogens through soils and aquifers". In: R. Mitchell New concepts in environmental microbiology, 19th edn. New York, Wiley, 1992.

6. U.J. Blumenthal, D.D. Mara, A. Peasey, G. Ruiz-Palacios, R. Stott, Bulletin of the World Health Organization, 2000, 78, 1104.

7. T. Asano, A.D. Levine, Wastewater reclamation, recycling, and reuse: an introduction. Asano, T. Wastewater reclamation and reuse. Technomic, Lancaster, PA, 1998.

8. W. Kondro, "E. coli outbreak deaths spark judicial inquiry in Canada", Lancet 355, 2000, 2058.

9. P. Mouchet, Journal American Water Works Association, 1992;84, 158.

10. B. Gaskill, Water Technology, 1996, 19, 10.

11. D. H. Paul, Water Science Technology, 1995, 18(9), 30.

12. G.S. Pellington, Water Review, 1992, 10(I), 1. 
13. J. Mc, Peak, Water Technology, 1988,11(5), 40.

14. M.C. Keller, Water Technology, 1995,18(9), 35.

15. Y.H. Zhang, Water Technology, 1996, 19(8), 81.

16. Water Quality Association. Water Treatment Fundamentals. Lisle, III; 1983.

17. J. Van Newenhizen, Water Technology, 1983, 21(I), 40.

18. T. Asano, D. Richard, R.W. Crites, G. Tchobanoglous, Water Science Technology, 1992, 4, :37.

19. Codex Alimentarius Commission. Proposed draft guidelines for the hygienic reuse of processing water in food plants. Codex Committee on Food Hygiene, FAO, 36th session, Washington D.C., USA, CX/FH/01/9; 2004.

20. Codex Alimentarius Commission. Procedural manual, 16th edn. ISSN 10208070. FAO, Rome; 2006.

21. Commission of the European Communities. Quality of water intended for human consumption, Council Directive 98/83/EC; 1998.

22. Law 458/2002, 311/2004, 107/1996, 311/2004, 112/2006, HG 188/2002, HG $352 / 2005$ (in Roumanian).

23. E. Gilca, A. Maicaneanu, P. Ilea, Central European Journal Chemistry, 2014, 12(8), 821.

24. A. Wolborska, Water Research, 1989, 23, 85.

25. H.C. Thomas, Jornal of the American Chemical Society, 1944, 66, 1466.

26. M. Dubinin, K. Nikolaev, N. Poljakov, L. Petrova, "Investigation of adsorption dynamics in a broad range of breakthrough concentrations". Institute of Physical Chemistry, Academy of Sciences of the USSR. Translated from Izvestiya Akademii Nauk SSSR, Seriya Khimicheskaya. 1972, 2, 1265.

27. M. Dubinin, K. Nikolaev, N. Poljakov, G. Pirozhkov, "Pore structures of charcoal adsorbents and the adsorbability of gases and vapors". Institute of Physical Chemistry, Academy of Sciences of the USSR, Moscow. Translated from Izvestiya Akademii Nauk SSSR, Seriya Khimicheskaya, 1980;8, 1728.

28. Y.H. Yoon, J.H. Nelson, American Industrial Hygiene Association Journal, 1984, 45, 509.

29. H. Bedelean, M Stanca, A. Maicaneanu, S. Burca, Studies and Research, Geology-Geography, 2005,10(53), 881.

30. M Stanca, A. Maicaneanu, S. Burca, H. Bedelean, Studia Universitatis BabeşBolyai Chemia, 2006, LI(2), 187.

31. A. Maicaneanu, H. Bedelean, M. Stanca, "Zeolitii naturali. Caracterizare si aplicatii in protectia mediului", Cluj University Press, Cluj-Napoca, Romania; 2008. 